\title{
SISTEM PENDUKUNG KEPUTUSAN DENGAN METODE TOPSIS UNTUK PENYELEKSIAN PENERIMAAN SISWA BARU Jajang Nurjaman ${ }^{1}$, Harunur Rosyid ${ }^{2}$, Putri Aisyiyah Rakhma Devi ${ }^{\text {() }}$ \\ ${ }^{1)}$ SD Islam Terpadu Al Ibrohimi Gresik
}

Jl. PP. Al Ibrohimi 01/40 Manyarejo Manyarejo Kec. Manyar Kab. Gresik

${ }^{2,3)}$ Teknik Informatika, Universitas Muhammadiyah Gresik, Jl. Sumatera No. 101 GKB, Gresik. e-mail: aajajang6719@gmail.com ${ }^{1)}$, harun.umgresik@gmail.com ${ }^{2}$.

\begin{abstract}
ABSTRAK
Penerimaan siswa baru merupakan agenda rutin tahunan bagi sebuah sekolah. Semakin tinggi kualitas sekolah yang bersangkutan, maka semakin banyak peminat siswa yang akan mendaftarkan diri sebagai siswa baru pada sekolah tersebut, sehingga untuk mendapatkan sumber daya siswa yang berkualitas maka perlu dilakukan penyeleksian secara akademik maupun non akademik pada proses penerimaan 'siswa baru.Proses yang dilaksanakan oleh pihak sekolah sekarang menggunakan perhitungan rata-rata dari beberapa kriteria penilaian yaitu tes baca dan tulis, berhitung dan mengamati, berkreasi dengan menggambar, dan mengaji. Permasalahan dalam pelaksanaan seleksi calon siswa baru yakni ada calon siswa yang tersisihkan karena hasil nilai tesnya kurang cukup padahal dia memiliki capaian prestasi cukup baik sebagai seorang siswa. Kualitas siswa yang baik tidak hanya di tentukan pada nilai tes saja, Namun capaian prestasi juga perlu di perhitungkan karena siswa perlu mengembangkan soft skill. Kriteria selain nilai tes, prestasi siswa mestinya bisa dijadikan kriteria dalam menentukan rekomendasi siswa yang layak diterima. Dalam penelitian ini,akan dibangun Sistem Pendukung Keputusan dalam memudahkan sekolah SD Islam Terpadu Al Ibrohimi Gresik pada proses`penerimaan siswa baru dengan Menggunakan Metode Technique for Order by Similarity to Ideal Solution(Topsis). Kriteria yang digunakan adalah Nilai tes baca, tes tulis, tes mengamati, tes berhitung, tes berkreasi, tes mengaji, dan prestasi. Aplikasi pada penelitian ini diimplementasikan dengan menggunakan bahasa pemograman Visual Basic. Dan Data Base menggunakan SQL server. Dari hasil pengujian aplikasi yang telah dibangun, perbandinvan hasil perhitungan manual dengan sistem di ambillo alternatif yang di hitung menggunakan metode TOPSIS menghasilkan nilai tertinggi 100, terendah 0, dari hasil pengujian yang telah dilakukan menggunakan Aplikasi Sistem Pendukung Keputusan Penyeleksian Siswa baru di SD islam terpadu Al Ibrohimi Gresik.
\end{abstract}

Kata Kunci: Sistem Pendukung Keputusan, TOPSIS, Siswa Baru.

\begin{abstract}
Admission of new students is an annual routine agenda for a school. The higher the quality of the school concerned, the more interested students will enroll as new students at the school, so to get quality student resources, it is necessary to select academically and non-academicly in the student admission process. new. The process carried out by the school now uses the average calculation of several assessment criteria, namely reading and writing tests, counting and observing, being creative by drawing, and reciting the Koran. The problem in implementing the selection of prospective new students is that there are prospective students who are excluded because the results of their test scores are not sufficient even though they have quite good achievements as a student. Good student quality is not only determined by test scores, but achievement also needs to be taken into account because students need to develop soft skills. Criteria other than test scores, student achievement should also be used as criteria to determine student recommendations that are worthy of acceptance. In this study, a Decision Support System will be built to facilitate the Al Ibrohimi Gresik Integrated Islamic Elementary School in the process of accepting new students using the Technique for Order by Similarity to Ideal Solution (Topsi) method. The criteria used are reading test scores, written tests, observing tests, counting tests, creative tests, reading tests, and achievements. The application in this research is implemented using the Visual Basic programming language. And Data Base using SQL server. From the results of testing applications that have been built, the comparison of the results of manual calculations with the system is taken 10 alternatives calculated using the TOPSIS method produce the highest score of 100, the lowest 0, from the results of tests carried out on the Decision Support System Application for Selection of New Students in Integrated Islamic Elementary School Al Ibrohimi Gresik.
\end{abstract}

Keywords: Decision Support System, TOPSIS, New Student.

\section{PENDAhuluan}

ualitas sebuah sekolah dipengaruhi oleh beberapa hal antara lain sarana dan prasarana serta sumber daya manusia termasuk didalamnya adalah guru, karyawan serta siswa yang dimiliki sekolah tersebut. Terkait kualitas sumber daya siswa suatu sekolah, maka erat kaitannya dengan proses penerimaan siswa baru. Penerimaan siswa baru merupakan agenda rutin tahunan bagi sebuah sekolah. Semakin tinggi kualitas sekolah yang bersangkutan, maka semakin banyak peminat siswa yang akan mendaftarkan diri sebagai siswa baru pada sekolah tersebut, sehingga untuk mendapatkan sumber daya siswa yang berkualitas maka perlu dilakukan penyeleksian secara akademik maupun non akademik pada proses`penerimaan siswa baru. 
INDEXIA: Informatic and Computational Intelegent Journal

Jajang Nurjaman, Harunur Rosyid, Putri Aisyiyah Rakhma Devi - Sistem Pendukung Keputusan Dengan Metode Topsis Untuk Penyeleksian Penerimaan Siswa Baru

SD Islam Terpadu Al Ibrohimi merupakan salah satu`lembaga pendidikan yang berada di Kecamatan Manyar Kabupaten Gresik yang bisa dijadikan sebagai rekomendasi sekolah bagi siswa yang telah menyelesaikan pendidikan pada tingkat TK sederajat. Dengan belum dimilikinya sistem informasi yang bisa mendukung suatu proses pengambilan keputusan dalam penerimaan siswa baru merupakan salah suatu kendala yang dihadapi oleh pihak sekolah. Proses yang dilaksanakan oleh pihak sekolah sekarang menggunakan perhitungan rata-rata dari beberapa kriteria penilaian yaitu tes baca dan tulis, berhitung dan mengamati, berkreasi dengan menggambar, dan mengaji. Permasalahan dalam pelaksanaan seleksi calon siswa baru yakni ada calon siswa yang tersisihkan karena hasil nilai tesnya kurang cukup padahal dia memiliki capaian prestasi cukup baik sebagai seorang siswa. Kualitas siswa yang baik tidak hanya di tentukan pada nilai tes saja, Namun capaian prestasi juga perlu di perhitungkan karena siswa perlu mengembangkan soft skill. Kriteria selain nilai tes, prestasi siswa mestinya bisa dijadikan kriteria dalam menentukan rekomendasi siswa yang layak diterima.Perlu dibangun sebuah sistem pendukung keputusan terkomputerisasi yang mampu membantu dalam menyimpan data siswa baru, hasil tes dan kemudian melakukan analisis terhadap hasil tes sehingga bisa memberikan alternatif solusi dalam memutuskan calon`siswa baru yang pantas diterima sesuai dengan penilaian kriteria-kriteria yang telah ditentukan oleh pihak sekolah sekaligus mempermudah pihak sekolah dalam proses penerimaan siswa baru serta pembuatan laporan yang dibutuhkan dengan cepat, tepat, dan akurat. Metode yang dipakai dalam sistem penyeleksian penerimaan siswa baru ini adalah Technique for Order Performace by Similarity to Ideal Solution (Topsis). Topsis ialah suatu bentuk metode pendukung keputusan yang didasarkan`pada konsep bahwa alternatif yang terbaiklah tidak hanya memiliki jarak terpendek dari suatu solusi ideal negatif yang dalam hal ini akan memberikan rekomendasi siswa yang berhak diterima atupun yang tidak diterima. Konsep tersebut banyak digunakan dalam menyeleksi masalah yang praktis. Konsepnya sederhana dan sangat'mudah dipahami, komputasinya efisien dan memiliki`kemampuan dalam mengukur kinerja relatif dari alternatif-alternatif keputusan dalam bentuk matematis yang sangat sederhana. Dari kondisi tersebut, maka skripsi ini mengambil judul "Aplikasi Sistem Pendukung Keputusan Dengan Metode Topsis Untuk Penyeleksian Penerimaan Siswa Baru di SD Islam Terpadu Al Ibrohimi Gresik". Sistem pendukung keputusan yang hendal dikembangkan akan menghasilkan output berupa rekomendasi calon siswa baru yang akan diterima sebagai siswa baru di SD Islam Terpadu Al Ibrohimi sesuai bobot. Kriteria yang digunakan untuk penyeleksian penerimaan siswa baru meliputi tes baca dan tulis, berhitung dan mengamati, berkreasi dengan menggambar, dan mengaji dan hasil dari kriteria tersebut ditampilkan dalam bentuk ranking mulai dari nilai tertinggi sampai nilai terendah.

\section{LANDASAN TEORI}

\subsection{Sistem Pendukung Keputusan (SPK) \\ 2.1.1 Pengertian SPK}

Sistem pendukung keputusan merupakan`sistem informasi berbasis komputer yang interaktif, dengan cara mengolah data dengan berbagai model dalam memecahkan masalah-masalah yang tidak terstruktur sehingga dapat memberikan informasi yang bisa digunakan oleh para pengambil keputusan dalam membuat sebuah keputusan. Dalam sebuah sistem pendukung`keputusan, sumber daya intelektual yang di miliki seseorang dipadukan dengan 'kemampuan komputer dalam membantu meningkatkan kualitas dari keputusan yang diambil. Pengambilan keputusan ialah sebuah proses memilih suatu tindakan diantara beberapa pilihan alternatif yang ada, sehingga tujuan yang diinginkan dapat tercapai. (Ahmad Abdul Chamid, 2016)

\subsubsection{Model Sistem Pendukung Keputusan}

Data dan informasi dimasukkan ke dalam database dari lingkungan perusahaan. Database juga berisi data yang disediakan oleh SIA, dan isi dari database digunakan oleh tiga subsistem perangkat lunak.

a. Perangkat penulis laporan, menghasilkan laporan periodik maupun khusus. Laporan periodik disiapkan sesuai jadwal dan dihasilkan oleh perangkat lunak. Laporan khusus disiapkan sebagai jawaban terhadap kebutuhan informasi yang tak terduga dan berbentuk database query oleh pemakai menggunakan query language dari database management system (DBMS).

b. Model matematika, menghasilkan sebagai hasil dari simulasi yang melipatkan satu atau beberapa komponen dari sistem fisik perusahaan, atau berbagai aspek`operasinya.

c. Groupware, memungkingkan beberapa pemecahan masalah, bekerja sama sebagai satu kelompok, dan mencapai solusi. Istilah GDSS atu sistem pendukung keputusan kelompok (group decision support system). Para anggota kelompok saling berkomunikasi baik secara langsung maupun melalui groupware.

\subsubsection{Komponen Sistem Pendukung Keputusan}

Sistem Pendukung Keputusan (SPK) merupakan implemeantasi teori- teori pengambilan keputusan yang diperkenalkan oleh ilmu-ilmu seperti: operation reseach dan management science. Hanya bedanya adalah jika dahulu dalam mencari penyelesaian yang sedang dihadapi harus dilakukan sebuah proses perhitungan interasi secara manual, saat ini komputer PC tela` menawarkan kemampuannya dalam menyelesaikan persoalan yang sama dalam waktu yang singkat. Komponen Sistem Penunjang Keputusan terdiri dari tiga komponen utama (Jogiyanto, 2003), yaitu :

1. Dialog Management atau user interface, yaitu komponen untuk berdialog dengan pemakai sistem. Komponen ini didalam sistem informasi ialah komponen input dan komponen output 
INDEXIA: Informatic and Computational Intelegent Journal

Jajang Nurjaman, Harunur Rosyid, Putri Aisyiyah Rakhma Devi - Sistem Pendukung Keputusan Dengan Metode Topsis Untuk Penyeleksian Penerimaan Siswa Baru

2. Model management, yaitu komponen yang dapat mengubah data menjadi informasi yang relevan. Model-model ini yang banyak dipergunakan dalam sistem penunjang keputusan adalah model matematika optimasi`seperti linear programming, dynamic programming, dan lain-lain sebagainya.

3. Data Management, merupakan komponen basis data yang terdiri dari semua basis data yang bisa diakses. Seperti sistem informasi pada umumnya, sistem penunjang keputusan juga mempunyai komponen lain seperti komponen teknologi dan kontrol. Komponen teknologi tersebut terdiri dari perangkat keras dan perangka` lunak. Perangkat lunak spesifik yang digunakan pada DSS misalnya adalah spreadsheet, database management system, dan query language

\subsubsection{Karakteristik Sistem Pendukung Keputusan}

Karakteristik sistem pendukung keputusan adalah:

1. SPK dirancang untuk membantu pengmbilan keputusan dalam memecahkan masalah yang sifatnya terstruktur mapun tidak terstruktur.

2. Dalam proses pengelolahanya, SPK mengombinasikan penggunaan model-model/ teknik-teknik analisis dengan teknik pemasukkan data konversional serta fungsi-fungsi pencari/ introgasi informasi.

Dengan berbagai karaketr khusus diatas, SPK dapat memberikan sebagai manfaat dan keuntungan. Manfaat yang dapat diambil dari SPK adalah:

1. SPK memperluas`kemampuan pengambilan keputusan saat memproses data atau informasi bagi pemiliknya.

2. SPK membantu mengambil keputusan untuk mememcahkan masalah terutama`berbagai masalah yang sangat komleks dan tidak terstruktur.

\subsection{Multi-Attribut Decision Making (MADM)}

\subsubsection{Pengertian Multi-attribut Decision Making (MADM)}

Multiple criteria decision making merupakan suatu metode dalam pengambilan keputusan untuk menetapkan alternatif terbaik dari sejumlah alternatif berdasarkan beberapa kriteria tertentu. Kriteria tersebut biasanya berupa suatu ukuran-ukuran, aturan-aturan atau standar yang digunakan saat pengambilan keputusan. Berdasarkan tujuannya CDM dapat terbagi menjadi 2 model yaitu model (Zimmermann, 1991): Multi Attribute Decision Making (MADM) dan Multi Objective Decision Making (MODM). Pada MADM yang biasanya dipergunakan dalam melakukan penilaian atau seleksi terhadap beberapa alternatif dalam jumlah yang terbatas, sedangkan MODM dipergunakan dalam menyelesaikan masalah-masalah pada ruang kontinyu (seperti pada program matematis), Secara umum bisa dikatakan bahwa MADM menyeleksi alternatif terbaik dari jumlah alternatif sedangkan MODM merancang alternatif terbaik.

Ada beberapa fitur umum yang digunakan dalam MCDM (Janko, 2005), yaitu:

1. alternatif, alternatif merupakan obyek-obyek yang berbeda dan`memiliki kesempatan yang sama untuk dipilih dalam pengambil keputusan.

2. Atribute, atribute dapat disebut sebagai karakteristik komponen atau criteria`keputusan. Namun kebanyakan kriteriatersebut bersifat satu level meskipun tidak menutup kemungkinan terdapat sub kriteria yang berhubungan dengan kriteria yang sudah diberikan.

3. Konflik antar kriteria, terdapat beberapa kriteria yang biasanya memiliki konflik antara yang satu dengan yang lainnya sepertinya kriteria keuntungan akan`mengalami konflik dengan kriteria biaya.

4. Bobot keputusan, bobot keputusan menunjukkan`kepentingan relatif dari`setiap kriteria $\mathrm{W}=(\mathrm{W} 1, \mathrm{~W} 2$,

...Wn) pada MCDM akan dicari bobot kepentingan dari setiap kriteria.

5. Matriks keputusan, suatu matriks keputussan $X$ yang berukuran $m \times n$ yang berisi elemen-elemen xij yang merepresentasikan`rating dari alternatif $\mathrm{Ai}(\mathrm{i}=1,2, \ldots . . \mathrm{n})$.

\subsection{Metode Topsis (Technique for Order Preference by Similarity to ideal solution)}

Topsis (Technique for Order Performance by Similarity to Ideal Solution) merupakan salah satu metode dalam pengambilan`keputusan multikriteria yang`pertama kali diperkenalkan oleh Yoon dan Hwang (1981). TOPSIS menggunakan prinsip bahwa alternatif yang terpilih harus mempunyai jarak terdekat dari solusi ideal positif dan harus memiliki jarak terpanjang dari solusi ideal negatif dari sudut pandang geometris dengan menggunakan jarak Euclidean (jarak antara dua titik) dalam menentukan kedekatan relatif dari suatu alternatif dengan solusi optimal (Kusumadewi, 2006).

Topsis banyak digunakan dalam beberapa model MADM untuk menyelesaikan masalah keputusan secara praktis. Hal ini dikarenakan:

1. Topsis memiliki konsep yang sederhana dan mudah dipahami.

2. Komputasinya efisien. 
INDEXIA: Informatic and Computational Intelegent Journal

Jajang Nurjaman, Harunur Rosyid, Putri Aisyiyah Rakhma Devi - Sistem Pendukung Keputusan Dengan Metode Topsis Untuk Penyeleksian Penerimaan Siswa Baru

3. Memiliki kemampuan dalam mengukur kinerja relatif dari alternatif- alternatif keputusan dalam bentuk matematis yang sederhana.

Secara umum prosedur metode topsis mengikuti langkah-langkah berikut ini:

1. Membuat matriks keputusan yang ternormalisasi.

2. Membuat matriks keputusan yang ternormalisasi terbobot.

3. Menentukan matriks solusi ideal positif dan matriks solusi ideal negatif.

4. Menentukan jarak antar nilai setiap alternatif dengan matriks solusi ideal positif dan matriks solusi ideal’negatif.

5. Menentukan nilai preferensi dalam setiap alternatif.

2.3.1 Tahap-Tahap Metode Topsis

Berikut beberapa langkah-langkah dalam menggunakan metode topsis:

2.3.1.1 Matriks KeputusanTernormalisasi

Langkah pertama adalah menormalisasikan matriks keputusan, normalisasidilakukanpadasetiapatributmatriks, normalisasidilakukan dengancaramembandingkansetiapatribut padasuatualternatifdengan akar jumah kuadrat setiap elemen kriteria yang sama pada semua alternatif.Berikutadalahpersamaanuntukmelakukannormalisasipada setiap atribut matrikskebutuhan.

$$
r_{i j} \frac{x_{i j}}{\sqrt{\sum_{i=1}^{m} x_{i j}^{2}}}
$$

Dimana rij adalah nilai atribut yang telah ternormalisasi Dengan $i=1,2, \ldots, \mathrm{m}$. Dan $\mathrm{j}=1,2, \ldots, \mathrm{n}$. Dan xij adalah matriks keputusan.

2.3.1.2 Pembobotan nilai Matriks Keputusanternormalisasi

Selanjutnya adalah, membuat matriks ternormalisasi terbobot dengan dilambangkan Y. Pembobotan nilai dilakukan dengan mengalikan matriks keputusan ternormalisasi dengan elemen pada vektor bobot preferensi dengan dilambangkan W. Berikut adalah persamaan untuk pembobotan:

$\mathrm{Y}_{\mathrm{ij}}=\mathrm{W}_{\mathrm{i}} \times \mathrm{r}_{\mathrm{ij}}$

Dengan Yij merupakan matriks ternomalisasi terbobot, Wi merupakan vektor bobot, dan rij merupakan matriks ternormalisasi. Dengan bobot $\mathrm{W}=(\mathrm{w} 1, \mathrm{w} 2, \mathrm{Wn})$.

2.3.1.3 Menentukan solusi ideal Positif dan Negatif

a. Solusi idealpositif

Solusi ideal positif dapat ditentukan berdasarkan rating bobot yang ternormalisasi (Yij). Dengan persamaan berikut:

$$
\mathrm{A}^{+}=\left(\mathrm{Y}^{+}, \mathrm{Y}^{+}, \ldots \mathrm{Y}^{+}\right)
$$

b. Solusi idealnegatif

Solusi ideal positif juga dapat ditentukan berdasarkan rating bobot yang ternormalisasi (Yij). Vektor solusi ideal negatif dilambangkan dengan $\mathrm{A}^{+}$Dengan persamaan berikut:

$$
A^{-}=\left(Y_{1}^{-}, Y_{2}^{-}, \ldots Y_{n}^{-}\right)
$$

2.3.1.4 Menentukan jarak antara nilai setiap alternatif dengan matriks solusi ideal positif dan`negatif.

A) Jarak terhadap solusi ideal'positif

Jarak antara alternatif Ai dengan solusi ideal positif telah dirumuskan sebagai berikut:

$$
D_{i}^{+}=\sqrt{\sum_{j}^{n}=_{1}\left(Y_{i}^{+}-Y_{i j}\right)^{2}}
$$

B) Jarak terhadap solusi idealnegatif

Jarak antara`alternatifAidengan solusi ideal negatif dirumuskan sebagai berikut: 
INDEXIA: Informatic and Computational Intelegent Journal

Jajang Nurjaman, Harunur Rosyid, Putri Aisyiyah Rakhma Devi - Sistem Pendukung Keputusan Dengan Metode Topsis Untuk Penyeleksian Penerimaan Siswa Baru

$$
\mathrm{D}_{\mathrm{i}}^{-}=\sqrt{\sum_{j=1}^{n}\left(Y_{i j}-Y_{i}^{-}\right)^{2}}
$$

Dimana:

$$
\begin{aligned}
& \mathrm{D}^{-}=\text {jarak alternatif dengan solusi ideal positif } \\
& Y_{i j}=\text { matriks normalisasiterbobot } \\
& Y_{i}^{-}=\text {solusi ideal negatif }
\end{aligned}
$$

2.3.1.5 Menentukan nilai preferensi untuk setiap`alternatif

Nilai preferensi merupakan nilai akhir yang menjadi patokan ketika menentukan peringkat pada semua alternatif yang ada. Berikut

adalah persamaan yang menggambarkan cara untuk mendapatkan nilai preferensi untuk setiap alternatif.

$$
\mathrm{V}_{\mathrm{i}}=\frac{D_{i}^{-}}{D_{i}^{-}+D_{i}^{+}}
$$

Dengan $0<\mathrm{V}_{\mathrm{i}}<1$ dan $\mathrm{i}=1,2,3, \ldots, \mathrm{m}$ Dimana:

$\mathrm{Vi}=$ kedekatan tiap alternatif terhadap solusi ideal positif

$D_{i}^{+}=$jarak alternatif Ai dengan solusi ideal positif

$D_{i}^{-}=$jarak alternatif Ai dengan solusi ideal negatif

\subsubsection{Merangkingalternatif}

Alternatif dapat dirangking berdasarkan urutan Vi Maka dari itu, alternatif terbaik adalah salah`satu yang berjarak terpendek terhadap solusi ideal dan berjarak terjauh dengan solusi negatifideal.Analisisdan Perancangan Sistem

\section{ANALISIS}

SD Islam Terpadu Al Ibrohimi merupakan salah`satu lembaga pendidikan`yang berada di Kecamatan Manyar Kabupaten Gresik yang bisa dijadikan sebagai rekomendasi sekolah bagi siswa yang telah menyelesaikan pendidikan pada tingkat TK sederajat. dalam pelaksanaan penerimaan calon siswa baru yakni di temui beberapa calon siswa yang memilki prestasi namun belum masuk perhitungan padahal capaian prestasi dibutuhkan sebagai penunjang penambahan nilai selain tes yang di tentukan oleh panitia pelaksana. Karena nilai prestasi siswa mestinya bisa dijadikan penunjang bagi calon siswa baru untuk menentukan rekomendasi siswa yang layak diterima. Dari permasalahan tersebut maka diperlukan adanya suatu sistem dalam`membantu proses penyeleksian calon siswa baru yang layak di terima

\subsection{Hasil Analisis}

Hasil analisis dari penelitian yang dilakukan menghasilkan keputusan untuk membuat sistem seleksi penerimaan siswa baru di SD Islam Terpadu Al Ibrohimi dengan menggunakan metode TOPSIS sebagai pendukung keputusan.

Secara umum sistem yang akan dibuat dalam penelitian ini meliputi beberapa proses sebagai berikut :

a.Penyimpanan data calon siswa .

Setiap calon siswa pendaftar akan memberikan informasi biodata siswa yang bersangkutan secara online dengan mengakses website yang telah disiapkan oleh pihak panitia dan menyerahkan berkas-berkas sebagai kelengkapan pendaftaran diserahkan kepada pihak panitia dengan waktu yang telah ditentukan.

b.Input kriteria penilaian.

Panitia penerimaan calon siswa menginputkan kriteria-kriteria yang digunakan sebagai pertimbangan penilaian penerimaan siswa.

c. Menentukan bobot.Dari kriteria-kriteria penilaian yang telah ditentukan, selanjutnya tiap-tiap kriteria diberikan nilai atau bobot untuk digunakan pada proses perhitungan.

d.Perhitungan topsis.

Proses ini dilakukan secara otomatis oleh sistem setelah kriteria dan pembobotannya telah ditentukan dan akan dihitung secara bersama dengan nilai-nilai dari tiap kriteria.

e.Perangkingan. 
INDEXIA: Informatic and Computational Intelegent Journal

Jajang Nurjaman, Harunur Rosyid, Putri Aisyiyah Rakhma Devi - Sistem Pendukung Keputusan Dengan Metode Topsis Untuk Penyeleksian Penerimaan Siswa Baru

Sistem akan merangking hasil perhitungan yang didapat secara urut dengan memperhitungkan kuota siswa ditetapkan oleh pihak sekolah, sehingga panitia penerimaan calon siswa akan lebih mudah dalam memutuskan diterima atau tidaknya calon siswa sebagai dasar pembuatan laporan.

f. Pembuatan laporan

Sistem akan memberikan informasi yang dapat digunakan sebagai dasar pembuatan laporan diantaranya laporan siswa pendaftar dan siswa yang diterima maupun tidak diterima.

Stakeholder (pihak yang terlibat dan berhubungan dengan sistem) dalam sistem ini adalah panitia penerimaan calon siswa yang memiliki akses penuh terhadap sistem mulai dari perekapan data calon siswa, penentuan kriteria, pembobotan sampai dengan pembuatan laporan.

Dengan adanya sistem ini diharapkan mampu memberikan informasi yang akurat dan efektif serta dapat mendukung dalam mengambil dan menentukan keputusan-keputusan dengan cara pemrosesan data menggunakan komputer. Informasi hasil perangkingan calon siswa baru diperoleh melalui proses penilaian akademik maupun non akademik dengan data calon siswa baru tersebut. Serangkaian proses tersebut dilakukan dengan cara komputerisasi. Sehingga efesiensi waktu serta keakuratan perhitungan dan informasi untuk perangkingan calon siswa baru menjadi terpenuhi.

Berikut gambaran alur penerimaan calon siswa baru dengan menggunakan metode TOPSIS.

Kebutuhan stackholder dalam sistem ini adalah sebagai berikut:



Gambar 1. Flowchart Penerimaan Siswa Baru Menggunakan Metode Topsis

Berdasarkan gambar 1 proses penyeleksian siswa baru dimulai dengan login ke dalam sistem kemudian memasukkan data dan data calon siswa kemudian dilakukan perhitungan menggunakan metode TOPSIS dengan bobot sesuai aturan yang telah ditetapkan oleh panitia seleksi selanjutnya dari hasil perhitungan didapatkan siswa yang layak diterima di SD Islam Terpadu Al Ibrohimi.

\subsection{Representasi Data}

\subsubsection{PenetuanBobotKriteria}

Data pembobotan ditentukan dari SD Islam Terpadu Al Ibrohimi dengan mengklasifikasikan tiap bobot pada kretieria. Data pembobotan tiap kriteria ditampilkan seperti tabel 1.

Tabel 1. Bobot masing-masing kriteria (W)

\begin{tabular}{|l|l|l|l|}
\hline No. & NamaKriteria & Bobot & Keterangan \\
\hline 1 & Tes Baca & SangatTinggi & C1 \\
\hline 2 & Tes Tulis & SangatTinggi & C2 \\
\hline 3 & Tes Berhitung & Tinggi & C3 \\
\hline 4 & Tes Mengamati & Tinggi & C4 \\
\hline 5 & Tes Berkreasi dengan menggambar & Cukup & C5 \\
\hline 6 & Tes Mengaji & Tinggi & C6 \\
\hline 7 & Prestasi & Rendah & C7 \\
\hline
\end{tabular}

Tingkat kepentingan kriteria atau bobot kriteria (W) dinilai $1-5$, dimana angka-angka ini hanya simbol peringkat tidak mengekspresikan jumlah, yaitu sebagai berikut :

$1=$ Sangat Rendah

$2=$ Rendah,

3 = Cukup, 
INDEXIA: Informatic and Computational Intelegent Journal

Jajang Nurjaman, Harunur Rosyid, Putri Aisyiyah Rakhma Devi - Sistem Pendukung Keputusan Dengan Metode Topsis Untuk Penyeleksian Penerimaan Siswa Baru

4 = Tinggi,

5 = Sangat Tinggi,

Untuk pengambilan keputusan untuk menyeleksi calon siswa baru ini memberikan bobot kriteria sebagai berikut :

$\mathrm{W}=[\mathrm{C} 1 ; \mathrm{C} 2 ; \mathrm{C} 3 ; \mathrm{C} 4 ; \mathrm{C} 5]$

$\mathrm{W}=$ [Sangat Tinggi; Cukup; Tinggi; Tinggi;Rendah $] \mathrm{W}=[5 ; 4 ; 3 ; 4 ; 2]$

Dalam menentukan bobot kriteria diatas, pertama diperlu adanya pengetahuan tentang`seberapa penting bobot tiap kriteria, tentunya dengan mengetahui bobot kriteria yang dibutuhkan, yaitu dengan `cara konsultasi terhadap bagian yang menangani penerimaan calon siswa`baru.

Tabel 2. merupakan penjelasan mengenai aturan penilaian dari setiap kriteria prestasi non akademik yang telah dijabarkan dengan cara pemberian nilai berdasarkan tingkat kejuaraan tertinggi hingga terendah.

Tabel 2. Aturan kriteria Prestasi.

\begin{tabular}{|r|c|c|}
\hline No. & TingkatKejuaraan & Nilai \\
\hline 1. & JuaraI,II, danIIITingkatInternasional & 100 \\
\hline 2. & JuaraI,II, danIIITingkatnasional & 90 \\
\hline 3. & JuaraI,II, danIIITingkatProvinsi & 80 \\
\hline 4. & JuaraI,II,danIIITingkatKabupaten & 70 \\
\hline 5. & Tanpa Prestasi & 60 \\
\hline
\end{tabular}

\subsubsection{Perangkingan Metode Topsis}

Pada proses ini akan dilakukan perangkingan dengan menggunakn metode Topsis, dalam penelitian ini akan digunakan beberapa data dari SD Islam Terpadu Al Ibrohimi yang terdiri 5 data, seperti yang terlihat pada Tabel 3.

Tabel 3. Sampel Nilai Calon Siswa

\begin{tabular}{|l|c|c|c|c|c|c|c|}
\hline NAMA & BACA & TULIS & MENGAMATI & BERHITUNG & BERKREASI & MENGAJI & PRESTASI \\
\hline $\begin{array}{l}\text { Achmad } \\
\text { Faisal Ha- } \\
\text { san }\end{array}$ & 24 & 66 & 20 & 90 & 85 & 80 & 70 \\
\hline $\begin{array}{l}\text { Adeeva } \\
\text { Farzana } \\
\text { Ayunindya }\end{array}$ & 100 & 100 & 80 & 100 & 85 & 96 & 60 \\
\hline $\begin{array}{l}\text { Aditya Az- } \\
\text { zam El } \\
\text { Shodiq }\end{array}$ & 92 & 100 & 100 & 95 & 85 & 84 & 60 \\
\hline $\begin{array}{l}\text { Ahmad } \\
\text { Sabiq Al } \\
\text { Fathin }\end{array}$ & 96 & 92 & 100 & 90 & 80 & 89 & 60 \\
\hline
\end{tabular}

Berikut ini adalah langkah-langkah dalam menyelesaikan permasalahan penerimaan siswa baru dengan menggunakan metode TOPSIS.

a. Membangun matriks keputusan

$$
\begin{aligned}
& \mathrm{X}=\left[\begin{array}{lrrrrrr}
X 11 & X 12 & X 13 & X 14 & X 15 & X 16 & X 17 \\
X 21 & X 22 & X 23 & X 24 & X 25 & X 26 & X 27 \\
X 31 & X 32 & X 33 & X 34 & X 35 & X 36 & X 37 \\
\cdots & \cdots & \cdots & \cdots & & \cdots & \\
X 41 & X 42 & X 43 & X 44 & X 45 & X 46 & X 47
\end{array}\right]
\end{aligned}
$$

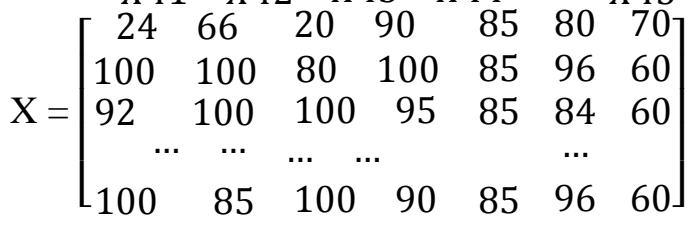

b. Hitung matriks keputusan ternormalisasi.

Setelah matriks keputusan didapat, maka langkah selanjutnya adalah menormalisasikan matriks keputusan. Sebelum dinormalisasikan maka akan dicari pembagi nilai dari setiap kriteria terlebih dahulu dengan akar jumlah kuadrat setiap alternatif dengan menggunakan persamaan (2.1). 
INDEXIA: Informatic and Computational Intelegent Journal

Jajang Nurjaman, Harunur Rosyid, Putri Aisyiyah Rakhma Devi - Sistem Pendukung Keputusan Dengan Metode Topsis Untuk Penyeleksian Penerimaan Siswa Baru

$$
\begin{aligned}
& \left|\mathrm{x}_{1}\right|=\sqrt{24^{2}+100^{2}+92^{2}+\cdots+40^{2}}=842 \\
& \left|\mathrm{x}_{2}\right|=\sqrt{66^{2}+100^{2}+100^{2}+\cdots+32^{2}}=791 \\
& \left|\mathrm{x}_{3}\right|=\sqrt{20^{2}+80^{2}+100^{2}+\cdots+100^{2}}=880 \\
& \left|\mathrm{x}_{4}\right|=\sqrt{90^{2}+100^{2}+95^{2}+\cdots+100^{2}}=868 \\
& \left|\mathrm{x}_{5}\right|=\sqrt{85^{2}+85^{2}+85^{2}+\cdots+80^{2}}=784 \\
& \left|\mathrm{x}_{6}\right|=\sqrt{80^{2}+96^{2}+84^{2}+\cdots+60^{2}}=784 \\
& \left|\mathrm{x}_{7}\right|=\sqrt{70^{2}+60^{2}+60^{2}+\cdots+80^{2}}=591
\end{aligned}
$$

\begin{tabular}{|c|c|c|c|c|c|c|c|}
\hline NAMA & BACA & TULIS & MENGAMATI & BERHITUNG & BERKREASI & MENGAJI & PRESTASI \\
\hline $\begin{array}{l}\text { Achmad Fai- } \\
\text { sal Hasan }\end{array}$ & 0,0285 & 0,0834 & 0,0227 & 0,1037 & 0,1084 & 0,102 & 0,1185 \\
\hline $\begin{array}{l}\text { Adeeva Far- } \\
\text { zana } \\
\text { Ayunindya }\end{array}$ & 0,1187 & 0,1263 & 0,0909 & 0,1152 & 0,1084 & 0,1224 & 0,1016 \\
\hline $\begin{array}{l}\text { Aditya Az- } \\
\text { zam El } \\
\text { Shodiq } \\
\end{array}$ & 0,1092 & 0,1263 & 0,1136 & 0,1095 & 0,1084 & 0,1071 & 0,1016 \\
\hline $\begin{array}{l}\text { Ahmad } \\
\text { Sabiq Al Fa- } \\
\text { thin }\end{array}$ & 0,114 & 0,1162 & 0,1136 & 0,1037 & 0,102 & 0,1135 & 0,1016 \\
\hline
\end{tabular}

Setelah diketahui pembagi dari masing-masing nilai kriteria, maka selanjutnya adalah membagikan setiap nilai matriks keputusan, dengan menggunakan persamaan (2.1). Sehingga hasilnya sebagai berikut:

$$
\begin{aligned}
& \mathrm{R}_{11}=\frac{X 11}{X 1}=\frac{24}{842}=0,0285 \\
& \mathrm{R}_{12}=\frac{X 12}{X 2}=\frac{66}{791}=0,0833 \\
& \mathrm{R}_{13}=\frac{X 13}{X 3}=\frac{20}{880}=0,0227 \\
& \mathrm{R}_{14}=\frac{X 14}{X 4}=\frac{90}{868}=0,1037 \\
& \mathrm{R}_{15}=\frac{X 15}{X 5}=\frac{85}{784}=0,1083 \\
& \mathrm{R}_{16}=\frac{X 16}{X 6}=\frac{80}{784}=0,1020 \\
& \mathrm{R}_{17}=\frac{X 17}{X 7}=\frac{70}{591}=0,1185
\end{aligned}
$$

Sehingga hasilnya dapat diperoleh matrik keputusan yang ternomalisasi pada tabel 4. berikut.

Tabel 4 Matrik keputusan yang ternomalisasi

c. Pembobotan Matrik Keputusan Ternomalisasi

Selanjutnya ialah dalam membuat matriks ternormalisasi terbobot yang dilambangkan Y, pembobotan tersebut dilakukan dengan `mengalikan setiap nilai pada matriks keputusan ternormalisasi $\mathrm{R}$ dengan`vektor bobot preferensi yang dilambangkan dengan $\mathrm{W}$ yang telah ditentukan sebelumnya. Dengan mnggunakan persamaan (2.2).

$$
\mathrm{R}==\left[\begin{array}{lllll}
0,0285 & 0,0834 & 0,0227 & 0,1037 & 0,10840,10200,1185 \\
0,1187 & 0,1263 & 0,0909 & 0,1152 & 0,10840,12240,1016 \\
0,1092 & 0,1263 & 0,1136 & 0,1095 & 0,10840,110710,1016 \\
0,1187 & 0,1074 & 0,1136 & 0,1037 & 0,10840,12240,1016
\end{array}\right]
$$

Dikalikan dengan W (bobot) :

$\mathrm{W}=[5,5,4,4,3,4,2]$

Sehingga diperoleh hasil matrik`keputusan ternomalisasi terbobot dapat dilihat pada tabel 5 .

Tabel 5 Matrik Keputusan Ternomalisasi Terbobot

\begin{tabular}{|l|l|l|l|l|l|l|l|}
\hline NAMA & BACA & TULIS & MENGAMATI & BERHITUNG & BERKREASI & MENGAJI & PRESTASI \\
\hline $\begin{array}{l}\text { Achmad Faisal Ha- } \\
\text { san }\end{array}$ & 0,1425 & 0,4169 & 0,0909 & 0,4149 & 0,3252 & 0,4081 & 0,2371 \\
\hline $\begin{array}{l}\text { Adeeva Farzana } \\
\text { Ayunindya }\end{array}$ & 0,5937 & 0,6317 & 0,3636 & 0,461 & 0,3252 & 0,4897 & 0,2032 \\
\hline $\begin{array}{l}\text { Aditya Azzam El } \\
\text { Shodiq }\end{array}$ & 0,5462 & 0,6317 & 0,4545 & 0,4379 & 0,3252 & 0,4285 & 0,2032 \\
\hline
\end{tabular}


INDEXIA: Informatic and Computational Intelegent Journal

Jajang Nurjaman, Harunur Rosyid, Putri Aisyiyah Rakhma Devi - Sistem Pendukung Keputusan Dengan Metode Topsis Untuk Penyeleksian Penerimaan Siswa Baru

\begin{tabular}{|l|l|l|l|l|l|l|l|}
\hline $\begin{array}{l}\text { Ahmad Sabiq Al Fa- } \\
\text { thin }\end{array}$ & 0,57 & 0,5812 & 0,4545 & 0,4149 & 0,306 & 0,454 & 0,2032 \\
\hline
\end{tabular}

d. Menentukan Solusi Solusi Ideal Positif dan Solusi Ideal Negatif

Menentukan nilai maksimal dan nilai minimum dari nilai terbobot setiap kriteria sehingga didapat solusi ideal positif dan solusi ideal negatif.

\section{Solusi Ideal Positif $(\mathrm{A}+)$}

Solusi ideal positif dicari dengan cara nilai terbesar dari nilai ternomalisasi terbobot, dengan menggunakan persamaan $(2.3)$.

$$
\begin{aligned}
& \mathrm{Y} 1^{+}=\max (0,14250,59370,5462 \ldots 0,2375)=0,5937 \\
& \mathrm{Y}^{+}=\max (0,41690,63170,6317 \ldots 0,2022)=0,6317 \\
& \mathrm{Y}^{+}=\max (0,09090,36360,4545 \ldots 0,4545)=0,4545 \\
& \mathrm{Y}^{+}=\max (0,41490,46100,4379 \ldots 0,461)=0,461 \\
& \mathrm{Y}^{+}=\max (0,32520,32520,3252 \ldots .0,306)=0,3443 \\
& \mathrm{Y}^{+}=\max (0,40810,48970,4285 \ldots .0,3061)=0,4999 \\
& \mathrm{Y}^{+}=\max (0,23710,20320,2032 \ldots .0,271)=0,271
\end{aligned}
$$

Sehingga dapat diketahui solusi ideal positif dari matriks ternomalisasi terbobot dapat dilihat pada tabel berikut :

Tabel 6 Hasil solusi ideal positif dari matriks ternomalisasi terbobot

\begin{tabular}{|c|c|c|c|c|c|c|c|}
\hline $\mathbf{A}+$ & 0,5937 & 0,6317 & 0,4545 & 0,461 & 0,3443 & 0,4999 & 0,271 \\
\hline
\end{tabular}

2. Solusi ideal negatif (A-)

Solusi ideal negatif dicari dengan mencari nilai terkecil dari nilai ternomalisasi terbobot.

$$
\begin{aligned}
& \mathrm{Y}^{-}=\min (0,14250,59370,5462 \ldots .0,2375)=0 \\
& \mathrm{Y}^{-}=\min (0,41690,63170,6317 \ldots 0,2022)=0 \\
& \mathrm{Y}^{-}=\min (0,09090,36360,4545 \ldots .0,4545)=0 \\
& \mathrm{Y}^{-}=\min (0,41490,46100,4379 \ldots .0,461)=0 \\
& \mathrm{Y}^{-}=\min (0,32520,32520,3252 \ldots .0,306)=0 \\
& \mathrm{Y}^{-}=\min (0,40810,48970,4285 \ldots 0,3061)=0 \\
& \mathrm{Y}^{-}=\min (0,23710,20320,2032 \ldots .0,271)=0,2032
\end{aligned}
$$

Sehingga dapat diketahui solusi ideal negatif dari matriks ternomalisasi terbobot dapat dilihat pada tabel berikut.

Tabel 7 solusi ideal negative dari matriks ternomalisasi terbobot.

\begin{tabular}{|l|l|l|l|l|l|l|l|} 
A- & 0 & 0 & 0 & 0 & 0 & 0 & 0,2032 \\
\hline
\end{tabular}

e. Menentukan jarak nilai alternatif dengan`matriks solusi ideal positif dan solusi ideal negatif :

1. Menentukan hasil jarak antara nilai setiap alternatif matriks ternormalisasi terbobot terhadap solusi ideal positif, dengan menggunakan persamaan (2.5). Sehingga hasilnya sebagai berikut :

$$
\begin{aligned}
& D_{1^{+}} \sqrt{\begin{array}{c}
(0,5937-0,1425)^{2}+(0,6317-0,4169)^{2}+(0,454-0,0909)^{2}+ \\
(0,461-0,4149)^{2}+(0,3443-0,3252)^{2}+(0,4999-0,4081)^{2}+(0,271-0,2371)^{2} \\
=0,6277
\end{array}} \\
& D_{2^{+}} \sqrt[\begin{array}{c}
(0,5937-0,5937)^{2}+(0,6317-0,6317)^{2}+(0,454-0,3636)^{2}+ \\
(0,461-0,461)^{2}+(0,3443-0,3252)^{2}+(0,4999-0,4897)^{2}+(0,271-0,2032)^{2} \\
=0,1154
\end{array}]{4} \\
& D_{3^{+}} \sqrt{\begin{array}{c}
(0,5937-0,5462)^{2}+(0,6317-0,6317)^{2}+(0,454-0,4545)^{2}+ \\
(0,461-0,4379)^{2}+(0,3443-0,3252)^{2}+(0,4999-0,4285)^{2}+(0,271-0,2032)^{2}
\end{array}=0,1133}
\end{aligned}
$$

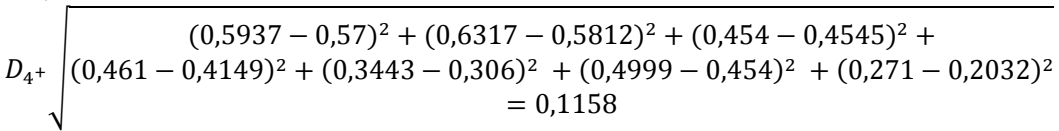

2. Menentukan hasil jarak antara nilai setiap alternatif matriks ternormalisasi terbobot terhadap solusi ideal negatif, dengan cara menggunakan persamaan (2.6). Maka hasilnya sebagai berikut

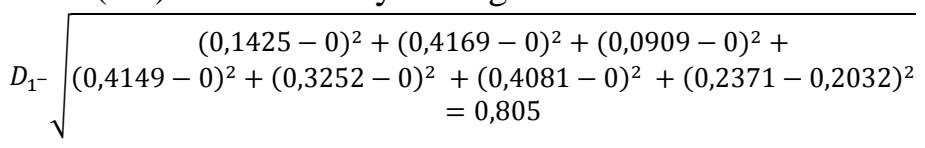


INDEXIA: Informatic and Computational Intelegent Journal

Jajang Nurjaman, Harunur Rosyid, Putri Aisyiyah Rakhma Devi - Sistem Pendukung Keputusan Dengan Metode Topsis Untuk Penyeleksian Penerimaan Siswa Baru

$$
\begin{aligned}
& D_{2^{-}} \sqrt{\begin{array}{c}
(0,5937-0)^{2}+(0,6317-0)^{2}+(0,3636-0)^{2}+ \\
(0,461-0)^{2}+(0,3252-0)^{2}+(0,4897-0)^{2}+(0,2032-0,2032)^{2} \\
=1,2008
\end{array}}
\end{aligned}
$$

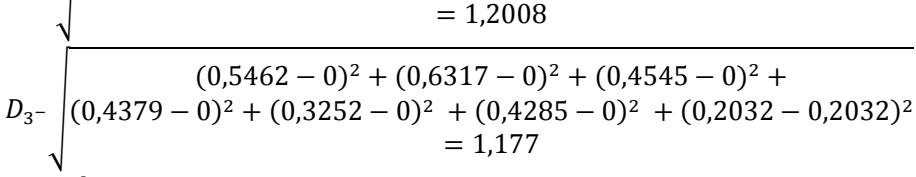

$$
\begin{aligned}
& D_{4^{-}} \sqrt{\begin{array}{c}
(0,57-0)^{2}+(0,5812-0)^{2}+(0,4545-0)^{2}+ \\
(0,4149-0)^{2}+(0,306-0)^{2}+(0,454-0)^{2}+(0,2032-0,2032)^{2} \\
=1,1581
\end{array}}
\end{aligned}
$$

Sehingga dapat diketahui hasil jarak antara nilai terbobot setiap alternatif terhadap solusi ideal positif dan solusi ideal negatif, seperti yang ada pada tabel 8 sebagai berikut:

\begin{tabular}{|c|c|c|}
\hline ALTERNATIF & D+ & D- \\
\hline A1 & 0,6277 & 0,805 \\
\hline A2 & 0,1154 & 1,2008 \\
\hline A3 & 0,1133 & 1,177 \\
\hline A $~$ & 0,1158 & 1,1581 \\
\hline
\end{tabular}

f. Menetukan nilai preferensi untuk setiap alternatif

Nilai preferensi adalah`nilai akhir yang akan menjadi patokan untuk menentukan peringkat pada setiap alternatif yang ada. Dilambangkan dengan huruf V. Perhitungan dicari dengan cara menentukan jarak kedekatan relatif dengan solusi ideal. Dengan menggunakan persamaan (2.7).

$$
\begin{aligned}
\mathrm{V} 1 & =\frac{0,805}{0,805+0,6277}=0,6215 \\
\mathrm{~V} 2 & =\frac{1,2008}{01,2008+0,1154}=0,9872 \\
\mathrm{~V} 3 & =\frac{1,177}{1,177+0,1133}=0,9869 \\
\mathrm{~V} 4 & =\frac{1,1581}{1,1581+1158}=0,986 \\
\mathrm{~V} 89 & =\frac{0,8416}{0,8416+0,592}=0,6668
\end{aligned}
$$

Setelah dihitung, sehingga hasilnya dapat diketahui pada Tabel 3.9.

Tabel 9 Kedekatan alternatif terhadap solusi ideal.

\begin{tabular}{|c|c|}
\hline & \multicolumn{2}{|c|}{ V } \\
\hline V1 & 0,6215 \\
\hline V2 & 0,9872 \\
\hline V3 & 0,9869 \\
\hline V4 & 0,986 \\
\hline
\end{tabular}

Sehingga dari nilai V didapat urutkan dari nilai terbesar sampai yang terkecil, hasilnya pada Tabel 10.

\begin{tabular}{|l|c|c|}
\hline \multicolumn{1}{|c|}{ Nama } & Nilai Prevensi & Rangking \\
\hline Achmad Faisal Hasan & 0,9872 & 1 \\
\hline Adeeva Farzana Ayunindya & 0,9869 & 2 \\
\hline Aditya Azzam El Shodiq & 0,986 & 3 \\
\hline Ahmad Sabiq Al Fathin & 0,6215 & 4 \\
\hline
\end{tabular}

\section{IMPLEMENTASIDAN PENGUJIAN SISTEM}

\subsection{Halaman Utama}

Halaman utama ketika pengguna berhasil masuk. Di halaman Utama terdapat halaman Beranda, Data Kriteria,Data Klasifikasi, Proses TOPSIS dan User seperti gambar 2. 
INDEXIA: Informatic and Computational Intelegent Journal

Jajang Nurjaman, Harunur Rosyid, Putri Aisyiyah Rakhma Devi - Sistem Pendukung Keputusan Dengan Metode Topsis Untuk Penyeleksian Penerimaan Siswa Baru



Gambar 2. Halaman Utama

\subsection{Hasil Analisa Pengujian Sistem}

Untuk proses pengujian sistem maka dilakukan proses pengujian dengan cara sebagai berikut:

1. Menggunakan 4 data calon siswa SD Islam Terpadu Al Ibrohimi Gesik 2020/2021

2. Percobaan penggunaan sistem dilakukan dengan memasukkan 4 data calon siswa SD Islam Terpadu Al Ibrohimi Gesik 2020/2021yang sudah di nilai berdasarkan kriteria berdasarkan reeferensi dari jurnal yang selanjutnya akan di proses dengan Metode TOPSIS.

3. Berdasarkan hasil pengujian sistem dapat disimpulkan bahwa pemilihan siswa berpresatsi menggunakan metode TOPSIS diperoleh hasil rekomendasi nilai prioritas tertinggi 0,9872dan nilai terendah 0,6215 .

Dimana hasil penyeleksian calon siswa baru yang telah dilaksanakan oleh pihak sekolah saat ini hanya berdasarkan rata-rata dari nilai Tes tulis, tes baca, tes mengamati, tes berhitung, tes berkreasi, tes mengaji, dan nilai prestasi. Sedangkan hasil penyeleksian calon siswa baru pada sistem dengan menggunakan metode TOPSIS berdasarkan kriteria yaitu nilai Tes tulis, tes baca, tes mengamati, tes berhitung, tes berkreasi, tes mengaji, dan nilai prestasi dimana setiap kriteria memiliki bobot kepentingan yang berbeda yang sudah ditentukan oleh pihak sekolah.

\section{PENUTUP}

\subsection{Kesimpulan}

Dari hasil pengujiana sistem pendukung keputusan dengan menggunakan metode TOPSIS ini, dapat membantu pihak sekolah dalam menentukan calon siswa baru yang berhak diterima atau tidak sehingga proses pengambilan keputusan ini dapat lebih efisien dan mempersingkat waktu panitia penerimaan siswa baru dalam mengambil keputusan.

\subsection{Saran}

Saran yang dapat disampaikan untuk pengembangan sistem kedepan, adalah sebagai berikut :

Sebaiknya dalam sistem ditambahkan fitur untuk menyimpan hasil proses perhitungan, karena saat ini sistem belum bisa menyimpan hasil perhitungan ketika dilakukan proses perhitungan dengan data yang baru.

\section{DAFTAR PUSTAKA}

Format dasar untuk buku:

[1] Kusumadewi, Sri. dkk. Fuzzy Multi-Attribute Decision Making (Fuzzy MADM). Yogyakarta: Graha Ilmu, 2006.

[2] Yakub. 2012. Pengantar Sistem Informasi, Yogyakarta: Graha Ilmu. 2012.

[3] Jogiyanto, H.M. (2003). Sistem Teknologi Informasi: Pendekatan Terintegrasi Konsep Dasar, Teknologi, Aplikasi, Pengembangan dan Pengelolaan. Edisi ke-1. Penerbit Andi Offset Yogyakarta.

[4] Wainright, Martin E., Carol V. Brown, Daniel DeHayes, Jeffrey A. Hoffer, and William C. Perkins (2002). Managing Information Technology. Fourth Edition. Prentice-Hall, New Jersey.

[5] Rudolphi, W. Multi Criteria Decision Analysis As A Framework For Integrated Land Use Management In Canadian National Parks. Canada: Simon Fraser University, 2000

[6] C.-L. Yoon, K.P., \& Hwang, "Multiple Attribute Decision Making: An Introduction,” Sage Univ. Pap. Ser. Quantative

[7] Appl. Soc. Sci., pp. 47-53, 1995.

[8] Ulum, Misbakhul. 2016, Aplikasi sistem pendukung keputusan dengan menggunakan metode topsis untuk menyeleksi penerimaan calon siswa baru (studi kasus : smk wachid hasyim glagah lamongan. Skripsi. Gresik : Universitas Muhammadiyah Gresik.

[9] Budi Utomo, Sanjaya. 2016, Sistem Pendukung Keputusan Pemberian Bonus Pegawai pada Hotel Saptanawa Gresik. Skripsi. Gresik : Universitas Muhammadiyah Gresik

[10] Mahabbah, A. M. Sistem Pemilihan Calon Peserta Lomba Lari Jarak Pendek Tingkat SLTP/MTS Sekabupaten Dengan Metode Topsis. Skripsi. Gresik: Universitas Muhammadiyah Gresik. 2013. 